\title{
Statistical Study of Current Trends in Mortgage Lending in Russia
}

\author{
Svetlana G. Babich ${ }^{1}$, Mikhail V. Karmanov ${ }^{1}$, Natalya N. Toropova ${ }^{2}$, Elizaveta S. Sokolova ${ }^{2}$, \\ Elnur T. Mekhdiev,"*
}

\begin{abstract}
${ }^{1}$ Department of Statistics, Plekhanov Russian University of Economics, Stremyanny lane, 36, Moscow, 117997, Russia ${ }^{2}$ Center for Analysis, Risk Management and Internal Control in Digital Space, Financial University under the Government of the Russian Federation, 49, Leningradsky Prospekt, Moscow, 125993, Russia
\end{abstract}

Received January 25, 2021; Revised March 8, 2021; Accepted March 30, 2021

\section{Cite This Paper in the following Citation Styles}

(a): [1] Svetlana G. Babich, Mikhail V. Karmanov, Natalya N. Toropova, Elizaveta S. Sokolova, Elnur T. Mekhdiev, "Statistical Study of Current Trends in Mortgage Lending in Russia," Universal Journal of Accounting and Finance, Vol. 9, No. 2, pp. 170 - 177, 2021. DOI: 10.13189/ujaf.2021.090204.

(b): Svetlana G. Babich, Mikhail V. Karmanov, Natalya N. Toropova, Elizaveta S. Sokolova, Elnur T. Mekhdiev (2021). Statistical Study of Current Trends in Mortgage Lending in Russia. Universal Journal of Accounting and Finance, 9(2), 170 - 177. DOI: 10.13189/ujaf.2021.090204.

Copyright $(2021$ by authors, all rights reserved. Authors agree that this article remains permanently open access under the terms of the Creative Commons Attribution License 4.0 International License

\begin{abstract}
Mortgage lending is one of the most important and most socially significant sectors of the national economy. Today, mortgage in Russia is rather underdeveloped and has a significant impact only on the economy of large cities. The development of mortgage in the Russian regions is hampered by the non-diversified approach to this issue. The article presents the results of analysis of housing mortgage loans dynamics in Russia. The number and volume of mortgage loans issued to individuals were assessed by regional structure. The Russian federal entities were grouped by the main indicators that affect the housing mortgage market. This allowed forming a basis for creating a strategy for the development of mortgage in Russia in the long term. Given the lack of a close relationship between mortgage lending and the situation in the housing market (in Moscow and St. Petersburg the demand for mortgage is higher than in other regions), the author has formed a more complex diversified model of regional distribution of mortgage lending. The author has also measured the dependence of the volume of housing mortgage loans on the main socioeconomic factors The key finding of the article is that the most serious factors affecting mortgage lending in Russia are the factors that need to be influenced, specifically the volume of wages, housing prices at current prices, as well as the level of employment in the economy.
\end{abstract}

Keywords Housing Mortgage, Dynamics, Structure, Cluster Analysis, Correlation, Russia

Gel classification: $\mathrm{C} 1, \mathrm{~A} 1, \mathrm{G} 2$

\section{Introduction}

The transition to a market-oriented economy model contributed to the development of the housing market. Purchasing own home is a top priority for every family. The solution of housing problem is important not only to citizens, but also to a state as a whole.

Mortgage lending is the provision by a bank of long-term loans to individuals and legal entities secured by real estate (for instance, for purchase of land, dwellings and industrial buildings) [1].

The role of mortgage significantly increases when economy is in an unsatisfactory state, since a developed and efficient mortgage system helps to reduce inflation, on the one side, and address social and economic issues, on the other side [2].

With the increase in the population's money income, the desire of citizens to improve their housing conditions grows, and therefore the role of housing mortgage increases. Currently, solving social problems, including housing, is one of the top priorities of Russian society. 
Furthermore, the increase in the volume of residential construction depends to a greater extent on the funds raised in this field through the development of mortgage lending.

Mortgage lending promotes the housing sales and construction sectors, which in turn contributes to the production of building materials, the development of construction machinery and woodworking industry, etc.

The development of housing mortgage has a significant socioeconomic effect and contributes to the growth in assets of various market entities and the encouragement of Investments in the real the economy, ensuring thus the stable growth of income in different sectors of the economy. Mortgage lending solves the acute problem of housing for citizens, improves the population's employment and solvency and ensures the growth of the country's GDP [3].

Today, mortgage lending is one of the most promising areas for the development of bank lending. Due to the novel coronavirus pandemic, the situation with mortgage lending in Russia becomes more difficult. However, mortgage loans are in high demand with the population, despite a tough economic situation and a decline in real income [4].

The literature on mortgage loans in Russia is scarce (the author has found 18 articles in Scopus). [5] greatly contributed to this study; the authors analyzed the situation on the Russian mortgage market and identified the most promising regions for mortgage lending, further suggesting that these regions were least affected by the financial crisis that occurred in Russia after the imposition of sanctions. The main findings in [5] correlate with findings in [6], in which the authors assessed the efficiency of commercial banks for the economy of the Russian federal entities using mathematical methods [7] defined the similarities and differences between mortgage models in different countries and suggested that Russia adhere to the German model, providing a significant analysis of the factors influencing the Russian economy. [4] described the possibilities of using a maternity capital in the Russian mortgage system and proved that this is an important factor for analyzing the regional distribution of mortgage in Russia. [8] provided an innovative idea focusing on escrow as a new financial instrument in the Russian mortgage system.

Taking into account the difficult situation with mortgage loans in Russia and high economic and social importance of the system, the authors pursue the goal to substantialize the major factors, contributing to the differences in mortgage lending in Russia and to figure out the most and the least successful regions in this sphere. The objective leads to the necessity to fulfill several tasks, namely, estimation of the mortgage dynamics, the clusterization of regions and the analysis of the results received.
The hypothesis of the article is that the sustainable development of the mortgage system in Russia will be achieved through differentiated politics for different regions, which are to be clusterized.

The research is of high significance due to both the importance of the issue, described above and because of the lack of such kind of researches on the theme of mortgage lending in Russia, although the country has a big housing market and a high demand for financial services in the sphere of mortgage credits. The article forms a basis for future research on the mortgage system in Russia and the ways of its development in future.

\section{Literature Review}

The system of mortgage loans differs depending on the country. In developed economies this system has overcome significant transformations and today needs little or nearly no reforms. The developing economies, on the other hand, differ significantly in their finical sector performance and attitude toward mortgage [11] gives a brief overview of the global situation in the developing economies in the sphere of mortgage loans and proves the bad situation with mortgages in Russia (the country is 12-th from the end of the list of countries by mortgage use). The other interesting research on the theme of housing [12] covers the external effects of housing and mortgage in developing economies. The authors state, that only institutional reforms can help develop the housing system, especially in the economies, suffering from the problems, similar to the Russian ones - diversified incomes, corruption, low investment attractiveness. Both articles don't cover Russia specifically.

When it comes to the research of the situation in Russia, the first work to get acquainted with is [13]. It covers the materials and methods used in order to assess the current situation in Russia. It lies in the basis of this paper in the segment of methodology. The current situation in Russian mortgage industry is covered in [14], where the authors state, that the situation in the country is becoming better, but significant changes in regulation of the industry are still needed, just as the big role of the state in the financial sector is justified. The new trends in banking, covering mortgage and securitization of debts is covered in [15]. The authors demonstrate, that the new trends in finance have contributed to the development of the Russian mortgage sector. Risk analysis of loans in Russia is given in [16], where the authors describe the major risks of the Russian financial system, giving implications on how to assess these risks constantly.

All in all, the works on the Russian mortgage system are scarce and lack the regional approach, so in the framework of the current researches this paper will allow to conduct new fundamental researches, based on the regional differentiation in Russia. 


\section{Materials and Methods}

In order to fulfil the tasks of the paper, the authors have used the following methodology. The analysis of current tendencies in housing mortgage is conducted using time series analytical indicators. The author has assessed the number of granted loans by regional structure and the volume of mortgage loans by federal districts. By comparing the situation now and 10 years ago, the authors have a significant time span, which includes the different economic situation in Russia, hence, the authors can ensure that the analysis conducted has fundamental, not conjunctural reasons.

Forecast models are based on the trend extrapolation method. Due to the limited initial data, the forecast estimates will be given up to 2022. The linear extrapolation doesn't grant significant accuracy, but allows to capture the main trend, hence, the authors use time as independent variable:

$$
f(t)=a t+b
$$

where $t$ stands for time series.

The author has used the method of cluster analysis with the SPSS software to group the Russian federal entities by the main indicators that affect the volume of mortgage loans provided to the population. The indicators for the grouping are the following: volume of housing mortgage loans issued, million rubles; number of housing mortgage loans issued, units; weighted average loan term, months; weighted interest rate, $\%$; average annual number of employed in the economy, thousand people; unemployment rate, \%; per capita money income of the population, rubles per month; average monthly salary, rubles; housing brought into use, million $\mathrm{m}^{2}$;average prices in the primary housing market, rubles. All the mentioned indicators contribute to the formation of the framework for mortgage giving and taking and have both economic and social significance, leading to the fundamental long run results of cluster analysis. Such number of indicators allows to cut down the conjuncture factors in order to assess the long-run role of economic situation in the mortgage system. The data for these indicators was taken for the same period - from 2011 to 2019 in order to unify the time scope of the research.

This grouping serves as the basis for future studies of the regional distribution of financial resources in the Russian economy.

The information base consists of data from the Russian statistics agency (Rosstat) and the Central Bank of Russia.

\section{Results and Discussion}

\section{A. Dynamics of the number of mortgage loans}

According to the Central Bank of Russia (CBR), the number of housing mortgage loans granted to the population in early 2019 amounted to 1471.82 thousand units, representing an increase of 4.89 times over the beginning of 2011 mainly due to the positive dynamics of ruble loans $[9,10]$. The number of loans granted in rubles for the same period increased by 4.94 times, amounting to 1471.81 thousand units, and in foreign currency - from 3192 units to 12 units (Fig. 1).

In 2018, there was a significant increase in the volume of mortgage loans compared to the previous year (by $49.0 \%$ ), with a reduction in interest rates and an increase in the loan term.

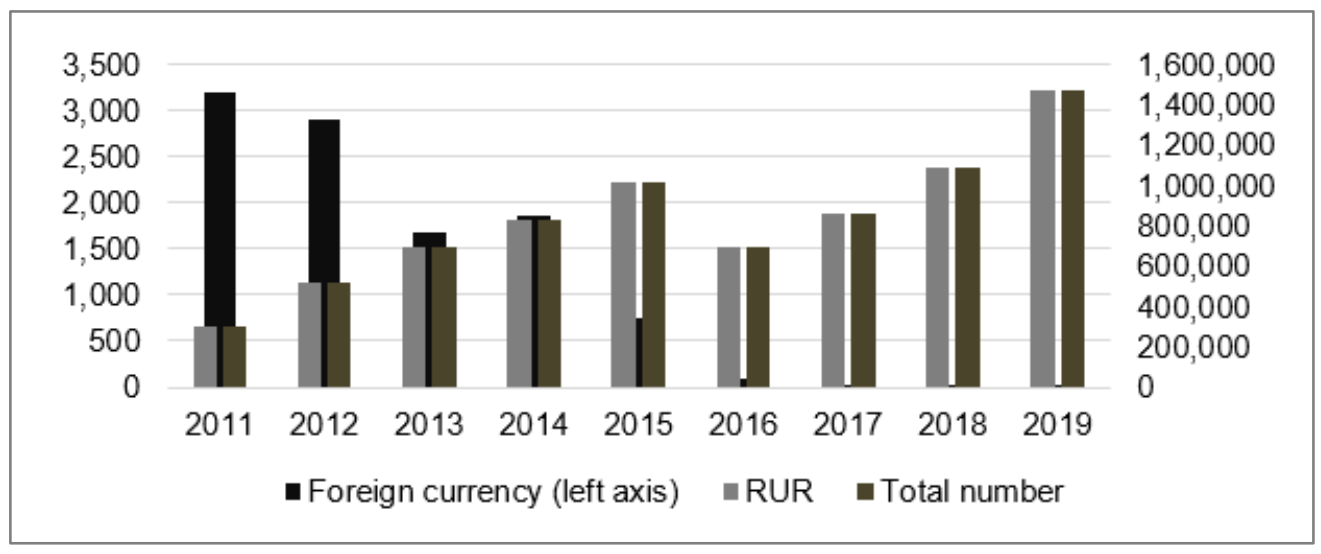

Source: created by the author, based on $[9,10]$.

Figure 1. Number of mortgage loans granted to individuals, units (as of the beginning of year). 
The highest number of mortgage loans in early 2019 was observed in the Volga federal district (356,274 units, which is 4.5 times more compared to January 1,2011). The lowest number was observed in the North Caucasian federal district $(33,046$ units, which increased almost five times during the study period).

Table 1. Number of housing mortgage loans granted to individuals in the Russian federal districts (as of the beginning of year).

\begin{tabular}{|c|c|c|c|c|}
\hline \multirow{2}{*}{ Federal districts } & \multicolumn{2}{|c|}{ Number of loans, units } & $\begin{array}{c}\text { Change in the number } \\
\text { of loans }\end{array}$ \\
\cline { 2 - 5 } & 2011 & 2019 & units & $\%$ \\
\hline Central & 56,867 & 353,706 & 296,839 & 522 \\
\hline Northwestern & 24,513 & 175,165 & 150,652 & 615 \\
\hline Southern & 18,717 & 116,713 & 97,996 & 524 \\
\hline North Caucasian & 6,657 & 33,046 & 26,389 & 396 \\
\hline Volga & 79,513 & 356,274 & 276,761 & 348 \\
\hline Ural & 45,249 & 165,424 & 120,175 & 266 \\
\hline Siberian & 55,530 & 192,856 & 137,326 & 247 \\
\hline Far Eastern & 13,989 & 78,637 & 64,648 & 462 \\
\hline
\end{tabular}

Source: created by the author, based on $[9,10]$.

Table 1 shows a noticeable increase in the number of housing mortgage loans issued in all federal districts from 2011 to the beginning of 2019 .

\section{B. Regional structure of mortgage loans}

At the beginning of 2011 and in 2019, the largest share of mortgage loans in Russia was reported in the Volga federal district $-26.4 \%$ and $24.2 \%$, respectively, and the lowest share was reported in the North Caucasian federal district $(2.2 \%$ and $2.2 \%$, respectively). During the study period the share of the Volga, Ural and Siberian federal districts decreased, and, for example, the share of the Central and Northwestern federal districts increased from $18.9 \%$ to $24.0 \%$ and from $8.1 \%$ to $11.9 \%$, respectively. (Fig. 2).

The obtained value of the Ryabtsev index of structural differences IR $=0.116$ shows that from 2011 to 2018 there was a low difference in the number of housing mortgage loans by the federal districts of Russia.

\section{Dynamics of the volume of mortgage loans}

The volume of housing mortgage loans in the country during the study period increased by 7.95 times, amounting to 3013.1 billion rubles by the beginning of 2019. At the same time, the main growth is due to the positive dynamics of ruble loans - by 8.28 times to 3012.7 billion rubles, while the volume of loans in foreign currency decreased from 15,267 million rubles to 413 million rubles (Fig. 3).

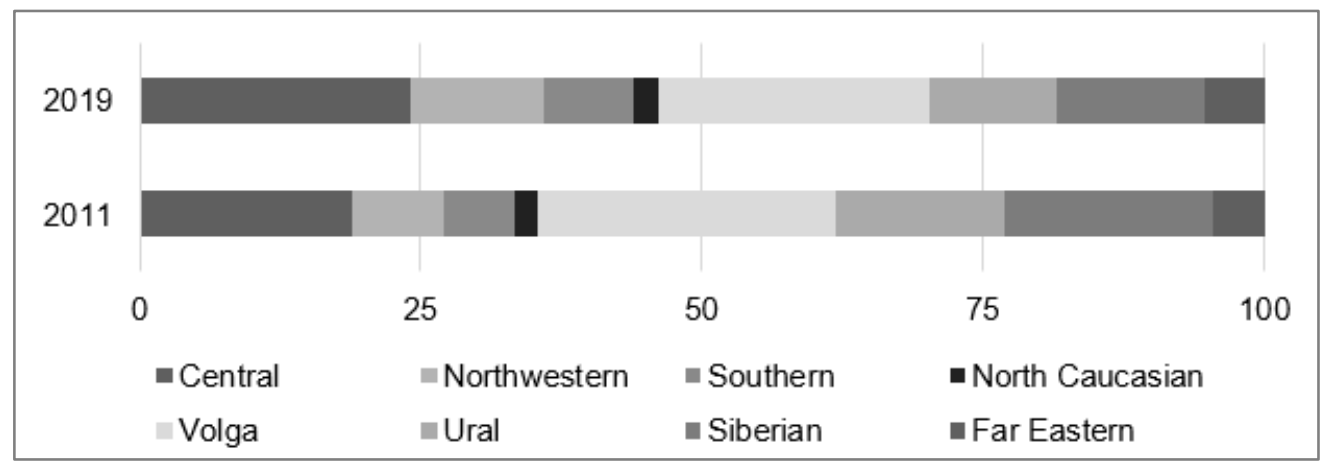

Source: created by the author, based on $[9,10]$.

Figure 2. Housing mortgage loans for individuals by the Russian federal districts, \% (as of the beginning of year).

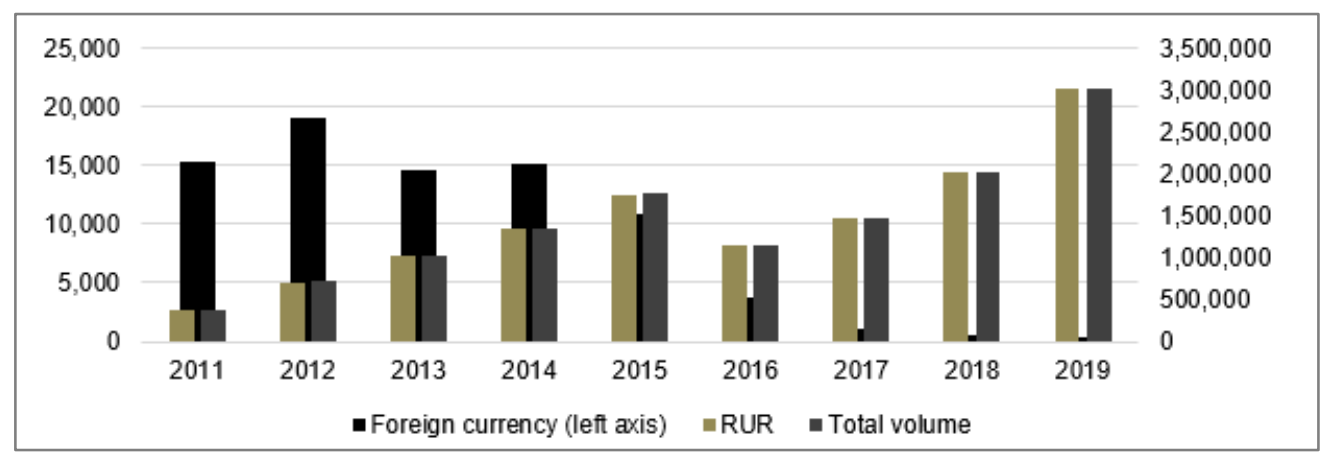

Source: created by the author, based on $[9,10]$.

Figure 3. Dynamics of the volume of housing mortgage loans for individuals in Russia, million rubles (as of the beginning of year). 


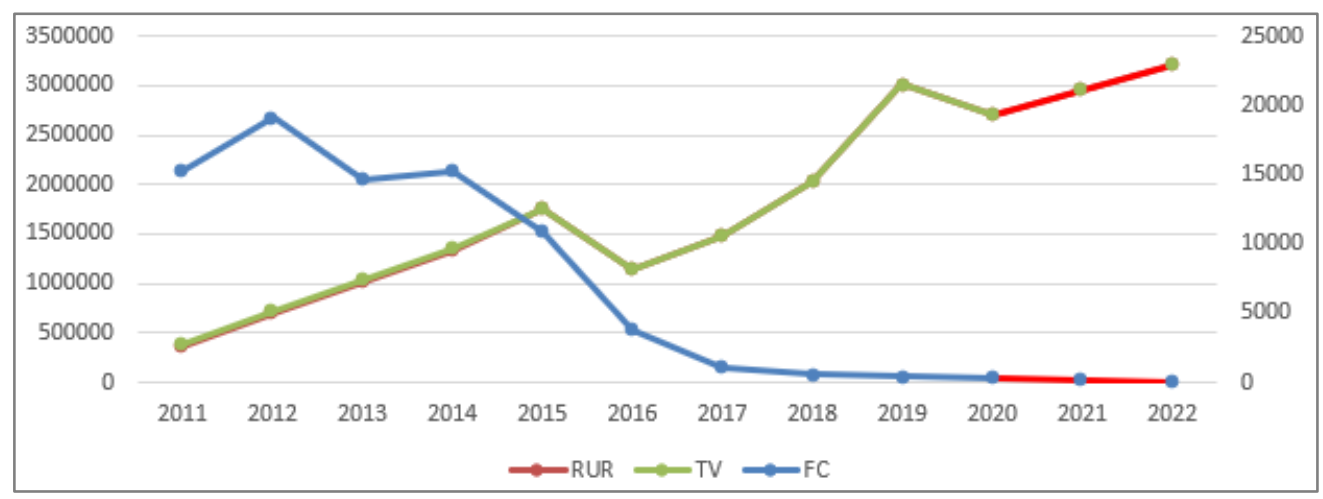

Figure 4. The dynamics of the housing mortgage in Russia (calculated by authors)

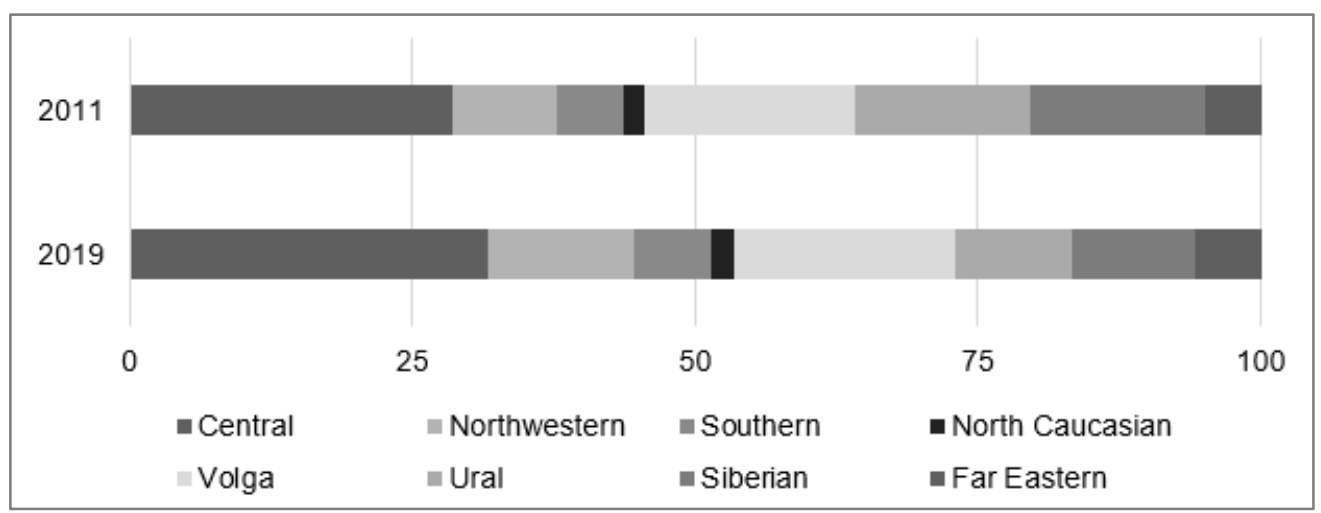

Source: created by the author, based on $[9,10]$.

Figure 5. Volume of mortgage loans issued in the Russian federal districts, \% (as of the beginning of year)

Table 2. Dynamics of the volume of loans granted to individuals in the Russian federal districts (as of the beginning of year).

\begin{tabular}{|c|c|c|c|c|}
\hline \multirow{2}{*}{ Federal districts } & \multicolumn{2}{|c|}{$\begin{array}{l}\text { Volume of mortgage } \\
\text { loans, million rubles }\end{array}$} & \multicolumn{2}{c|}{ Change in the volume } \\
\cline { 2 - 5 } & 2011 & 2019 & Million rubles & $\%$ \\
\hline Central & 108,088 & 955,813 & 847,725 & 784 \\
\hline Northwestern & 35,079 & 387,745 & 352,666 & 1005 \\
\hline Southern & 22,568 & 208,393 & 185,825 & 823 \\
\hline North Caucasian & 6,869 & 60,721 & 53,852 & 784 \\
\hline Volga & 70,729 & 584,877 & 514,148 & 727 \\
\hline Ural & 58,339 & 312,739 & 254,400 & 436 \\
\hline Siberian & 58,447 & 326,334 & 267,887 & 458 \\
\hline Far Eastern & 18,814 & 176,493 & 157,679 & 838 \\
\hline
\end{tabular}

Source: created by the author, based on $[9,10]$.

As shown in Table 2, from 2011 to the beginning of 2019 there was a diverse dynamics of the volume of mortgage loans issued in the Russian federal districts. The Central federal district is in the lead by the volume of housing mortgage loans $(955.8$ billion rubles at the beginning of 2019 , which is 8.8 times more compared to the beginning of 2011). The smallest number of housing mortgage loans issued in the same period was reported in the North Caucasian federal district $(60.7$ billion rubles, which increased by 8.8 times).

Figure 4 demonstrates the results of the linear regression analysis. In accordance with the data provided the dynamics of the foreign currency loans are negative and are going to zero in the nearest years.

The overall growing dynamics of mortgage credits in Russia prove the need of this financial instrument in Russia.

At the beginning of 2019, mortgage loans in foreign currency were issued only in two federal districts - in the Central (388 million rubles) and Volga (25 million rubles).

\section{Regional structure of the volume of issued mortgage loans}

Fig. 4 presents the regional structure of the volume of mortgage loans issued in 2011 and 2019. The share of the Central and Northwestern federal districts increased from $28.5 \%$ to $31.7 \%$ and from $9.3 \%$ to $12.9 \%$, respectively. While the share of the Ural and Siberian federal districts decreased by $5.0 \%$ to $10.4 \%$ and $10.8 \%$, respectively.

It is concluded from the obtained results that there is a significant differentiation in the development of mortgage lending in the Russian federal entities. The following main factors influence the development of housing mortgage lending in Russia: general economic situation in 
the region; housing availability to individuals and the state of the housing stock; prices in the primary and secondary housing markets; housing affordability to certain groups of population; housing construction volume; the financial system development; availability of regional housing construction finance programs [5].

E. Multidimensional grouping of the Russian federal entities by the main indicators in housing mortgage lending

To assess the differentiation of the Russian federal entities by the main indicators affecting housing mortgage lending, the author has performed a multidimensional grouping of Russian federal entities using the k-average method. The following indicators were selected:

$x_{1}(y)$ - volume of housing mortgage loans issued, million rubles;

$x_{2}$ - number of housing mortgage loans issued, units; $x_{3}$ - weighted average loan term, months;

$x_{4}$ - weighted interest rate, $\%$;

$x_{5}$ - average annual number of employed in the economy, thousand people;

$x_{6}$ - unemployment rate, $\%$;

$x_{7}$ - per capita money income of the population, rubles per month;

$x_{8}$ - average monthly salary, rubles;

$x_{9}$ - housing brought into use, million $\mathrm{m}^{2}$;

$x_{10}$ - average prices in the primary housing market, rubles.

These indicators were collected by the authors, based on the methodology used in [17] and [18], where the authors conducted the analysis of the mortgage politics of a commercial bank and studied the market situation. As a result of the cluster analysis, 82 Russian federal entities were grouped into five clusters (Table 3 ).

Table 3. Grouping of the Russian federal entities into clusters by the main indicators in the field of mortgage loans (2018).

\begin{tabular}{|c|c|c|}
\hline Cluster & $\begin{array}{c}\text { Number of } \\
\text { federal entities }\end{array}$ & Federal entities \\
\hline 1 & 1 & City: Moscow \\
\hline 2 & 63 & $\begin{array}{l}\text { Republics: Karelia, Komi, Adygea, Kalmykia, Crimea, Dagestan, Ingushetia, Kabardino-Balkarian, } \\
\text { Karachay-Cherkess, North Ossetia (Alania), Chechnya, Mari El, Mordovia, Udmurt, Chuvash } \\
\text { (Chuvashia), Altai, Tuva, Khakassia, Buryatia, Sakha (Yakutia); } \\
\text { Territories: Altai, Zabaykalskiy, Kamchatka, Primorskiy, Khabarovsk; } \\
\text { Regions: Belgorod, Bryansk, Vladimir, Ivanovo, Kaluga, Kostroma, Kursk, Lipetsk, Oryol, Ryazan, } \\
\text { Smolensk, Tambov, Tver, Tula, Yaroslavl, Arkhangelsk, Vologda, Kaliningrad, Murmansk, Novgorod, } \\
\text { Pskov, Astrakhan, Volgograd, Kirov, Orenburg, Penza, Ulyanovsk, Kurgan, Irkutsk, Kemerovo, Omsk, } \\
\text { Tomsk, Amur, Magadan, Sakhalin; } \\
\text { Jewish Autonomous Region; } \\
\text { Chukotka Autonomous Area; } \\
\text { City: Sevastopol }\end{array}$ \\
\hline 3 & 1 & Region: Moscow \\
\hline 4 & 15 & $\begin{array}{c}\text { Republics: Bashkortostan, Tatarstan; } \\
\text { Territories: Stavropol, Perm, Krasnoyarsk; } \\
\text { Regions: Voronezh, Leningrad, Rostov, Nizhny Novgorod, Samara, Sverdlovsk, Saratov, Tyumen, } \\
\text { Chelyabinsk, Novosibirsk }\end{array}$ \\
\hline 5 & 2 & $\begin{array}{l}\text { Krasnodar Territory; } \\
\text { City: Saint Petersburg }\end{array}$ \\
\hline
\end{tabular}

Source: created by the author. 
The average values of the indicators in clusters 1 (Moscow city), 3 (Moscow region), and 5 (Krasnodar area and Saint-Petersburg city) are higher than the average values of the same indicators in clusters 2 and 4 . The federal entities with the lowest values form cluster 2 (Table 4).

Table 4. Average values of indicators in clusters.

\begin{tabular}{|c|c|c|c|c|c|}
\hline & Cluster 1 & Cluster 2 & Cluster 3 & Cluster 4 & Cluster 5 \\
\hline $\mathrm{X}_{1(\mathrm{Y})}$ & 50,494 & $1,868.7$ & 29,484 & $7,502.6$ & $17,407.5$ \\
\hline $\mathrm{X}_{2}$ & 9,724 & 940.5 & 8,420 & 3,696 & 6,173 \\
\hline $\mathrm{X}_{3}$ & 227.5 & 216.6 & 227.4 & 214.9 & 220 \\
\hline $\mathrm{X}_{4}$ & 9.0 & 9.1 & 8.9 & 9.1 & 9.0 \\
\hline $\mathrm{X}_{5}$ & $7,208.4$ & 503.1 & $4,075.3$ & 1,550 & $2,850.9$ \\
\hline $\mathrm{X}_{6}$ & 1.4 & 6.3 & 2.7 & 4.3 & 3.1 \\
\hline $\mathrm{X}_{7}$ & 68,386 & $27,637.1$ & $44,707.0$ & $30,177.1$ & $39,685.5$ \\
\hline $\mathrm{X}_{8}$ & $135,374.9$ & $50,694.6$ & $68,969.6$ & $50,504.1$ & $64,157.1$ \\
\hline $\mathrm{X}_{9}$ & $5,024.8$ & 485.6 & $8,610.9$ & $1,862.4$ & $3,974.2$ \\
\hline $\mathrm{X}_{10}$ & 203.2 & 48.4 & 88.5 & 54.2 & 86.6 \\
\hline
\end{tabular}

Source: the author's calculations.

Further, based on the matrix of paired correlation coefficients, the author has selected the following factors, which have a major impact on the results: $\mathrm{x}_{1}$ - volume of issued housing mortgage loans, million rubles; $\mathrm{x}_{2}-$ number of issued housing mortgage loans, units; $x_{5}$ average annual number of employed in the economy, thousand people; $x_{7}$ - per capita money income of the population, rubles per month; $x_{9}$ - housing brought into use, million $\mathrm{m}^{2} ; x_{10}$ - average prices in the primary housing market, rubles. The multiple correlation coefficient was calculated based on data for 2018 using the correlation and regression analysis; its value $(\mathrm{R}=$ 0.977 ) proves that the studied indicators are directly and closely interrelated. The value of determination coefficient $(\mathrm{R} 2=0.955)$ indicates that the volume of mortgage loans granted to the population is mainly determined (95.5\%) by factors $\mathrm{x}_{2}, \mathrm{x}_{5}, \mathrm{x}_{7}, \mathrm{x}_{9}$ and $\mathrm{x}_{10}$, and to a lesser extent ( $4.5 \%$ ) by other factors.

The identified main factors determining the volume of mortgage lending in Russia indicate that the distribution of mortgage lending in the Russian market is uneven and does not cover the basic needs of the population.

The investigation in social and demography factors in depth is not needed, as the clusterization is based on the economic situation in the regions. The deeper is the analysis of social factors, the more the clusters get mixed due to the influence of non-economic causes of mortgage acceptance. Hence, as it was already researched in [19] the results will be mixed because of the overall negative attitude to mortgage in Russia. These attitudes have become even worse because of the financial crisis and recent sanctions.

\section{Conclusions}

The obtained results allow to make several conclusions on the situation on the mortgage market in Russia.

1) Despite the positive dynamics of the number and volume of mortgage loans issued in Russia, the obtained results indicate a significant differentiation of the regions by the main indicators in the mortgage lending.

2) The Central federal district takes the lead in the number and volume of issued loans (mainly due to Moscow and the Moscow Region), and the Volga federal district as well (due to the Republics of Bashkortostan and Tatarstan, the Perm Territory, Nizhny Novgorod, Samara and Saratov Regions).

3) The most important factors that have a greater impact on the volume of housing mortgage loans are the number of issued loans, the average annual number of employed in the economy, the average per capita money incomes of the population, the volume of housing brought into use and average prices in the primary housing market.

4) The main factors that have a negative impact on the mortgage lending are the low level of money incomes of a significant part of the population, high interest rates, and the lack of long-term financial resources.

The combination of these factors along with the extensive economic policies of Russia lately proves the hypothesis that the differentiated regulations of mortgage crediting are to be introduced in Russia in order to overcome the negative dynamics of mortgage lending.

\section{REFERENCES}

[1] L. A. Shafirov, "Sustainable Lending for Housing Projects: Is Affordable Housing a Myth for Depressed Russian Monotowns?," ACRN Oxford Journal of Finance and Risk Perspectives, Vol. 6, No. 3 (Special Issue FRAP/SSFII Conference), pp. 71-88, 2017.

[2] T. J. Pinkowish, Residential mortgage lending: principles and practices, Sixth edition, Mason, OH: Cengage Learning, 2012 .

[3] A. V. Mishura, S. V. Bekareva, E. N. Meltenisova, "Concentration in the banking sector and housing lending in Russian regions," Voprosy Ekonomiki, No. 4, pp. 107-128, 2020. DOI: 10.32609/0042-8736-2020-4-107-128.

[4] M. Ermilova, D. Ushakov, "The use of European experience in mortgage lending in Russian conditions," Revista Espacios, Vol. 40, No. 13, p. 27. 
[5] O. V. Savchina, O. V. Savchina, A. L. Bobkov, A. Z. Sharashidze, "On the State of the Mortgage Market in the Russian Federation in the Conditions of Global Economic Crisis," Journal of Applied Economic Sciences, Vol. XI, No. 6, pp. 1097-1101, 2016.

[6] H. Ternovskaya, A. Lavrishko, "The Influence of the Credit Policy of Commercial Banks on the Modernization of the Russian Economy Structure," Journal of Reviews on Global Economics, Vol. 7, pp. 433-441, 2018. DOI: 10.6000/1929-7092.2018.07.37.

[7] M. Ermilova, V. Nikeriasova, "Models of Mortgage Lending: Cross-Country Evidence," Academy of Accounting and Financial Studies Journal, Vol. 22, No. 3, 2018, https://www.abacademies.org/articles/models-of-mortgagelending-crosscountry-evidence-7260.html (accessed Dec. 1, 2020).

[8] K. V. Ekimova, N. P. Nazarchuk, I. P. Denisova, and E. N. Gruzdneva. "The Concept of Special Escrow Accounts to Improve Mortgage Housing Loans in Russia," IJEBA, Vol. VII, No. Special Issue 2, pp. 135-146, 2019. DOI: $10.35808 / \mathrm{ijeba} / 378$.

[9] The Central Bank of the Russian Federation, "Bulletin of Banking Statistics (No. 2 (213))," Moscow, 2011 , http://cbr.ru/Collection/Collection/File/8119/Bbs1102e.pdf (accessed Dec. 1, 2020).

[10] The Central Bank of the Russian Federation, "Bank of Russia Statistical Bulletin (No. 1 (308))," Moscow, 2019, http://cbr.ru/Collection/Collection/File/14328/Bbs1901e.pd $\mathrm{f}($ accessed Dec. 1, 2020).

[11] Anton Badev, Thorsten Beck, Ligia Vado, and Simon Walley. Housing Finance Across Countries: New Data and Analysis, The World Bank Finance and Private Sector Development Global Capital Markets Department, Policy Research Working Paper 6756. 2014. Available at: http://documents1.worldbank.org/curated/en/697351468165 251669/pdf/WPS6756.pdf

[12] Robert Buckley. "Housing finance in developing countries: a transaction cost approach," Policy Research Working Paper Series 347, The World Bank. 1989.

[13] Korosteleva T.S., Tselin V.Y. Assessment of regional mortgage inequality: comparative analysis of methods and results // Vestnik of Samara University. Economics and Management. Vol. 11. - N. 3. - P. 92-106. 2020. doi: 10.18287/2542-0461-2020-11-3-92-106

[14] Olga Mashkina, Pila Heliste, Riitta Kosonen. The emerging mortgage market in Russia: An overview with local and foreign perspectives. 2007. Available at: http://epub.lib.aalto.fi/pdf/hseother/b82.pdf

[15] S. Yu. Khasyanova, M. E. Samsonov, "The estimation model of the mortgage securitization effect on banking business", Probl. Upr., 2020, no. 3, 40-48.

[16] Rumyantseva, Ekaterina \& Furmanov, Kirill, "Modeling mortgage survival," Applied Econometrics, Russian Presidential Academy of National Economy and Public Administration (RANEPA), vol. 41, pages 123-143. 2016.

[17] Sungjoo Hwang, Moonseo Park, Hyun-Soo Lee. Dynamic analysis of the effects of mortgage-lending policies in a real estate market, Mathematical and Computer Modelling, Volume 57, Issues 9-10, 2013, Pages 2106-2120.

[18] Agnello, L., Castro, V. \& Sousa, R.M. The Housing Cycle: What Role for Mortgage Market Development and Housing Finance?. J Real Estate Finan Econ 61, 607-670. 2020. https://doi.org/10.1007/s11146-019-09705-z

[19] Susan Kenyon. What do we mean by multitasking? Exploring the need for methodological clarification in time use research. International Journal of Time Use Research 2010, Vol. 7, No. 1, 42-60. 